\title{
Isoprene emissions track the seasonal cycle of canopy temperature, not primary production: evidence from remote sensing
}

\author{
P. N. Foster ${ }^{1}$, I. C. Prentice ${ }^{2,3}$, C. Morfopoulos ${ }^{4}$, M. Siddall ${ }^{1}$, and M. van Weele ${ }^{5}$ \\ ${ }^{1}$ Department of Earth Science, University of Bristol, Wills Memorial Building, Queens Road, Bristol, BS8 1RJ, UK \\ ${ }^{2}$ AXA Chair of Biosphere and Climate Impacts, Department of Life Sciences, Grand Challenges in Ecosystems and the \\ Environment and Grantham Institute for Climate Change, Imperial College, Silwood Park, Ascot, SL5 7PY, UK \\ ${ }^{3}$ Department of Biological Sciences, Macquarie University, North Ryde, NSW 2109, Australia \\ ${ }^{4}$ Department of Life Sciences, Imperial College, Silwood Park, Ascot, SL5 7PY, UK \\ ${ }^{5}$ Royal Netherlands Meteorological Institute, P.O. Box 201, 3730 AE De Bilt, the Netherlands
}

Correspondence to: P. N. Foster (pru.foster@bristol.ac.uk)

Received: 4 October 2013 - Published in Biogeosciences Discuss.: 13 December 2013

Revised: 14 May 2014 - Accepted: 16 May 2014 - Published: 1 July 2014

\begin{abstract}
Isoprene is important in atmospheric chemistry, but its seasonal emission pattern - especially in the tropics, where most isoprene is emitted - is incompletely understood. We set out to discover generalized relationships applicable across many biomes between large-scale isoprene emission and a series of potential predictor variables, including both observed and model-estimated variables related to gross primary production (GPP) and canopy temperature. We used remotely sensed atmospheric concentrations of formaldehyde, an intermediate oxidation product of isoprene, as a proxy for isoprene emission in 22 regions selected to span high to low latitudes, to sample major biomes, and to minimize interference from pyrogenic sources of volatile organic compounds that could interfere with the isoprene signal. Formaldehyde concentrations showed the highest average seasonal correlations with remotely sensed $(r=0.85)$ and model-estimated $(r=0.80)$ canopy temperatures. Both variables predicted formaldehyde concentrations better than air temperature $(r=0.56)$ and a "reference" isoprene model that combines GPP and an exponential function of temperature $(r=0.49)$, and far better than either remotely sensed green vegetation cover, fPAR $(r=0.25)$ or model-estimated GPP $(r=0.14)$. Gross primary production in tropical regions was anti-correlated with formaldehyde concentration $(r=-0.30)$, which peaks during the dry season. Our results were most reliable in the tropics, where formaldehyde observational errors were the least. The tropics are of particular interest because they are the greatest source of isoprene
\end{abstract}

emission as well as the region where previous modelling attempts have been least successful. We conjecture that positive correlations of isoprene emission with GPP and air temperature (as found in temperate forests) may arise simply because both covary with canopy temperature, peaking during the relatively short growing season. The lack of a general correlation between GPP and formaldehyde concentration in the seasonal cycle is consistent with experimental evidence that isoprene emission rates are largely decoupled from photosynthetic rates, and with the likely adaptive significance of isoprene emission in protecting leaves against heat damage and oxidative stress.

\section{Introduction}

Plants expend energy to emit remarkable amounts of isoprene (Sharkey et al., 2008), which in turn influences both atmospheric chemistry and the terrestrial carbon balance. The need to understand the regulation of oxidant (hydroxyl radical) concentration in the troposphere (Collins et al., 2001) has led to efforts to predict isoprene emission rates in a changing environment. Isoprene emission by plants shows a steep temperature dependence, and early modelling studies predicted that 21 st century climate change would greatly increase isoprene emission: with knock-on effects including elevated concentrations of ozone, a phytotoxin and a powerful greenhouse gas (Laothawornkitkul et al., 2009; Peñuelas and 
Staudt, 2010). Some experimental studies have found that high $\mathrm{CO}_{2}$ concentrations inhibit isoprene emission, counteracting this effect of increasing temperature (Possell et al., 2005; Arneth et al., 2007; Heald et al., 2009). However, one recent study showed that growth under elevated $\mathrm{CO}_{2}$ can result in high isoprene emission (Noe et al., 2012). The combined effect of climate and $\mathrm{CO}_{2}$ change on global isoprene emission is still unclear. Current models arrive at similar contemporary global isoprene emission but diverge in their predictions for the past or future time (Young et al., 2009). Many open questions remain as to the controls of isoprene emission over large regions and long (seasonal to multi-annual) timescales. In the work presented here, we address these controls empirically, using the seasonal cycle of remotely sensed formaldehyde concentration as a proxy for isoprene emission, and analysing its relationship to environmental predictors across a globally representative set of regions.

Some success has been achieved in modelling the environmental controls of isoprene emission, especially in the temperate zone. Two main strategies have been adopted. "Empirical" models are based on experimentally observed dependencies of isoprene emission on temperature, photosynthetically active radiation (PAR) and other factors (Guenther et al., 1993, 2006). "Process-based" models relate isoprene emission somehow to photosynthetic electron transport, but empirical modifiers have been used to account for further temperature and $\mathrm{CO}_{2}$ concentration effects (Arneth et al., 2007). On monthly and longer timescales, both of these techniques are linked to primary production, directly in the modelling studies and indirectly in the empirical models via PAR, which is proportional to primary production on these timescales (Ruimy et al., 1995). Current models capture the seasonal patterns of emission in temperate ecosystems quite well (Pacifico et al., 2011). Using remotely sensed formaldehyde concentrations and a chemistry-transport model to track the oxidation of isoprene to formaldehyde, Palmer et al. (2006) found that $75 \%$ of the seasonal cycle of isoprene emission in the warm-temperate southeastern USA could be explained by its temperature dependence as represented in Guenther and colleagues' Model of Emissions of Gases and Aerosols from Nature (MEGAN) (Guenther et al., 2006). A lower correlation $(r=0.41)$ between formaldehyde concentration and MEGAN predictions was found in the tropical western Amazon region (Barkley et al., 2008) however, and several other studies have concluded that the seasonal variation of isoprene in the tropics cannot be explained by air temperature and PAR alone (Serca et al., 2001; Kuhn et al., 2004). This is a critical point for global modelling as most isoprene emission occurs in the tropics (perhaps as much as $80 \%$, Guenther et al., 2006). The relatively weak predictive capability of current models in the tropics may have arisen in part because these models were developed based primarily on observations at temperate sites (Guenther et al., 2006; Sharkey et al., 2008; Pacifico et al., 2011).
Most tests of isoprene emission models have been carried out at the leaf level and on diurnal or shorter timescales (Monson et al., 2007, 2012; Guenther et al., 2006; Arneth et al., 2007). For global applications, it is also important to test models at larger spatial and temporal scales, but this cannot be done by direct measurement of emissions. Several studies have used modelled isoprene fluxes as input to global chemistry-transport models, and compared the results with remotely sensed formaldehyde concentrations (Palmer et al., 2003, 2006; Abbot et al., 2003; Fu et al., 2007; Shim et al., 2005; Barkley et al., 2008). These studies have established that formaldehyde concentration over the continents records the seasonal pattern of emissions of non-methane volatile organic compounds (VOCs), which in turn is dominated by isoprene and pyrogenic VOCs. Therefore, the contribution of direct emissions of formaldehyde to the seasonal cycle is negligible. Building on these findings, we used satellite observations of formaldehyde concentration (deSmedt et al., 2008) here as a direct proxy for the seasonal cycle of isoprene emission in fire-free regions. This approach, which greatly simplifies analysis of the remotely sensed data, was supported by an investigation of the controls on formaldehyde concentration in the TM5 chemistry-transport model (see Methods). We showed that atmospheric chemistry alone is very unlikely to account for the observed seasonal patterns of formaldehyde concentration, which were thus inferred to reflect seasonal variations in the emission of isoprene rather than variations in the rates of downstream chemical reactions.

The objective of this study was to discover possible empirical relationships between isoprene emission and potential environmental predictors that would apply globally, including in the tropics, on larger spatial scales and on longer (seasonal) timescales than can be considered in short-term experiments or based on point measurements. To this end, we carried out a comprehensive analysis of the correlations between the mean seasonal cycle of formaldehyde concentration, considered as a proxy for isoprene emission, and a series of potential predictors related to canopy temperature and primary production, as well as with a reference isoprene emission model that combines both elements. We focused on 22 fire-free regions spanning the range of latitudes and sampling all biomes in the land classification scheme of DeFries and Townsend (1994). We explored the use of canopy temperature as a predictor variable, using both remotely sensed land surface temperature and model-estimated values (based on Arneth et al. (2007) energy balance method), showing that the two approaches (a) yield consistent results and (b) outperform air temperature as a predictor of isoprene emission. We also quantify the predictive power of remotely sensed green vegetation cover (fPAR, a key indicator of the seasonal cycle of primary production) and modelled gross primary production (GPP). This set of variables collectively represents the major controls of isoprene emission as expressed in both empirical and process-based models. 


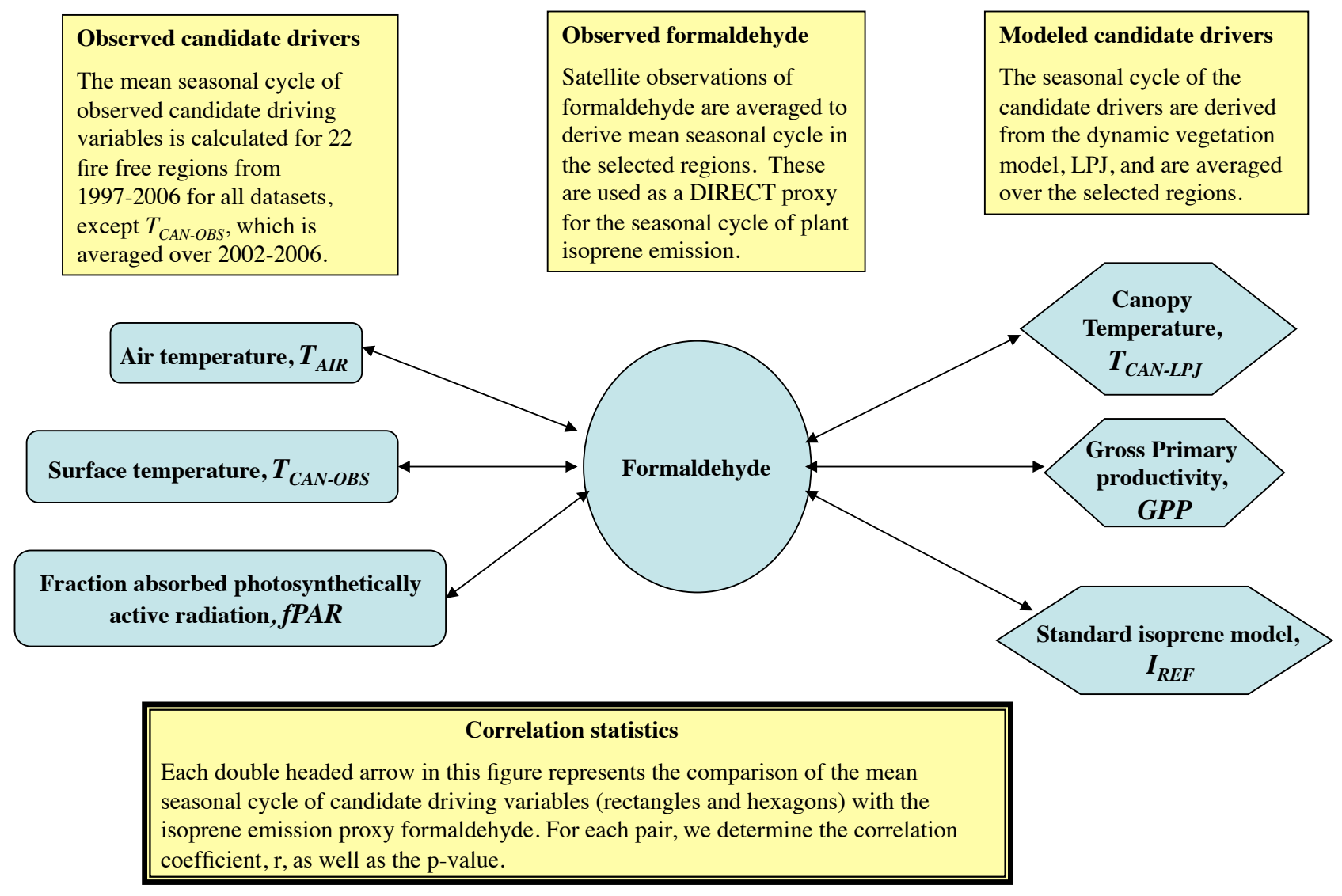

Figure 1. Schematic of the analysis. The blue boxes show variables averaged over selected regions and years to produce a mean seasonal cycle. The mean seasonal cycles of the observed and modelled variables are statistically compared with the mean seasonal cycle of satellite observations of formaldehyde - a direct proxy for plant isoprene emissions - shown in the blue circle. The "standard model" refers to the dynamic global vegetation model Lund-Potsdam-Jena (LPJ) and is based on Arneth et al. (2007).

\section{Methods}

\subsection{Comparing seasonal cycles}

We compared regionally averaged monthly means of formaldehyde concentration with similarly averaged values of potential predictor variables, using data for each month during 1997-2006 (2000-2006 for observed canopy temperature) to derive a mean seasonal cycle for each variable in each region, as summarized in Fig. 1. The selected regions are shown in Fig. 2. The predictor variables, selected on the basis of previous work (e.g. Guenther et al., 2006; Niinemets et al., 1999; Palmer et al., 2006; Barkley et al., 2008), comprise three measures of temperature ( $T_{\mathrm{AIR}}$, $T_{\mathrm{CAN}-\mathrm{OBS}}$ and $T_{\mathrm{CAN}-\mathrm{LPJ}}$, being air temperature, remotely sensed canopy temperature, and modelled canopy temperature, respectively); two measures related to total ecosystem photosynthesis (remotely sensed fPAR - the fraction of incident PAR absorbed by vegetation - and modelled GPP); and a reference isoprene emission model $\left(I_{\mathrm{REF}}\right)$ which is a joint function of GPP, $c_{\mathrm{i}}$ (the $\mathrm{CO}_{2}$ concentration inside the leaf) and an exponential function of temperature.

\subsection{Formaldehyde as a proxy for isoprene emission}

The seasonal cycle of formaldehyde over land could in principle be influenced by variations in the efficiency of the net chemical production or loss of formaldehyde, independently of isoprene emission rates. This is why previous analyses have input isoprene emission estimates into chemistrytransport models to predict atmospheric formaldehyde concentrations, which were then compared with remotely sensed observations of formaldehyde (Palmer et al., 2006; Barkley et al., 2008; Stavroakou et al., 2009; Marais et al., 2012). The following equation describes the atmospheric content of formaldehyde, $C$ :

$\mathrm{d} C / \mathrm{d} t=f I_{\text {total }}+P-C / \tau$,

where $t$ is time, $f$ is the efficiency of formaldehyde production per unit isoprene emission, $I_{\text {total }}$ is the isoprene emission rate, $P$ is the formaldehyde production rate from precursors other than isoprene, and $\tau$ is the lifetime of formaldehyde in the atmosphere. We assumed that the rate of change of $C$ is much smaller than the production rate. We ignored 

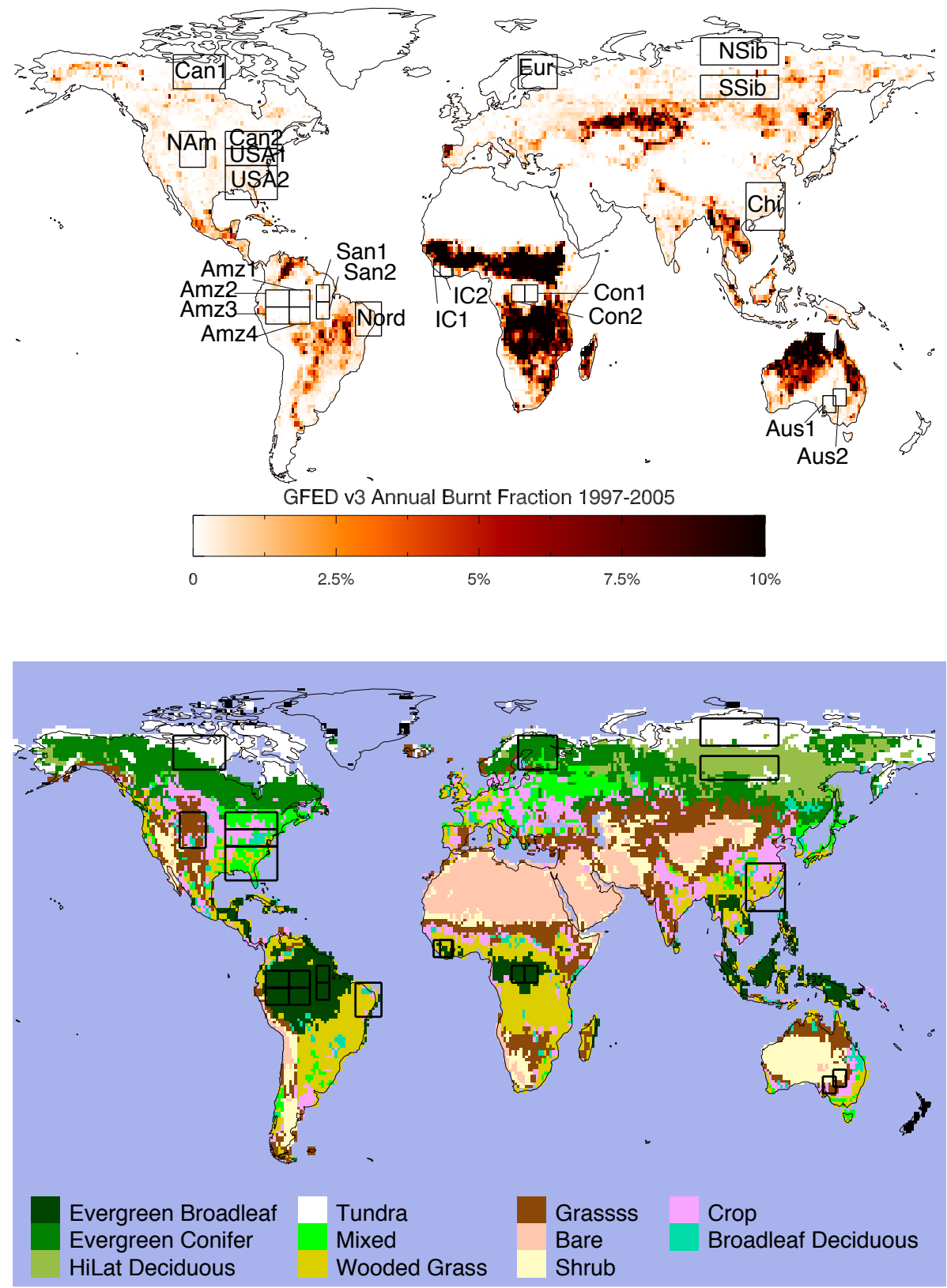

Figure 2. Geographic distribution of the regions analysed, overlayed on burnt area and biomes. Average burnt fraction (1997-2005) from version 3 of the Global Fire Emissions Database (van der Werf et al., 2010) is shown in the top panel. The bottom panel shows the land classification, following deFries and Townsend (1994).

the production of formaldehyde from non-isoprene sources as isoprene dominates the hydrocarbon flux from the biosphere to the atmosphere (Sharkey et al., 2008); although this may not be accurate in boreal regions where monoterpenes can exceed isoprene emissions. With these assumptions, $C=$ $f \tau I_{\text {total }}$ or equivalently, $C=A I_{\text {total }}$ where $A$ is the net chemical modulation of isoprene conversion into formaldehyde. We estimated the seasonal cycle of $A$ using the state-of-theart chemistry-transport model TM5 (Williams et al., 2012; Huijnen et al., 2010); this includes the CBM-4 chemical mechanism with 16 production and 4 destruction reactions for formaldehyde, including photolysis reactions (Table 3 of Huijnen et al., 2010). Along with burden changes, these approximately close the formaldehyde budget on a monthly timescale. Production and destruction terms per chemical reaction were stored during the simulation to facilitate the evaluation. Isoprene emissions in TM5 follow Huijnen et al. (2010) and are based on the 12-year climatology of the Organising Carbon and Hydrology In Dynamic Ecosystems (ORCHIDEE) model (Lathiere et al, 2006). Figure S1 in the 


\subsection{BOREAL SITES}
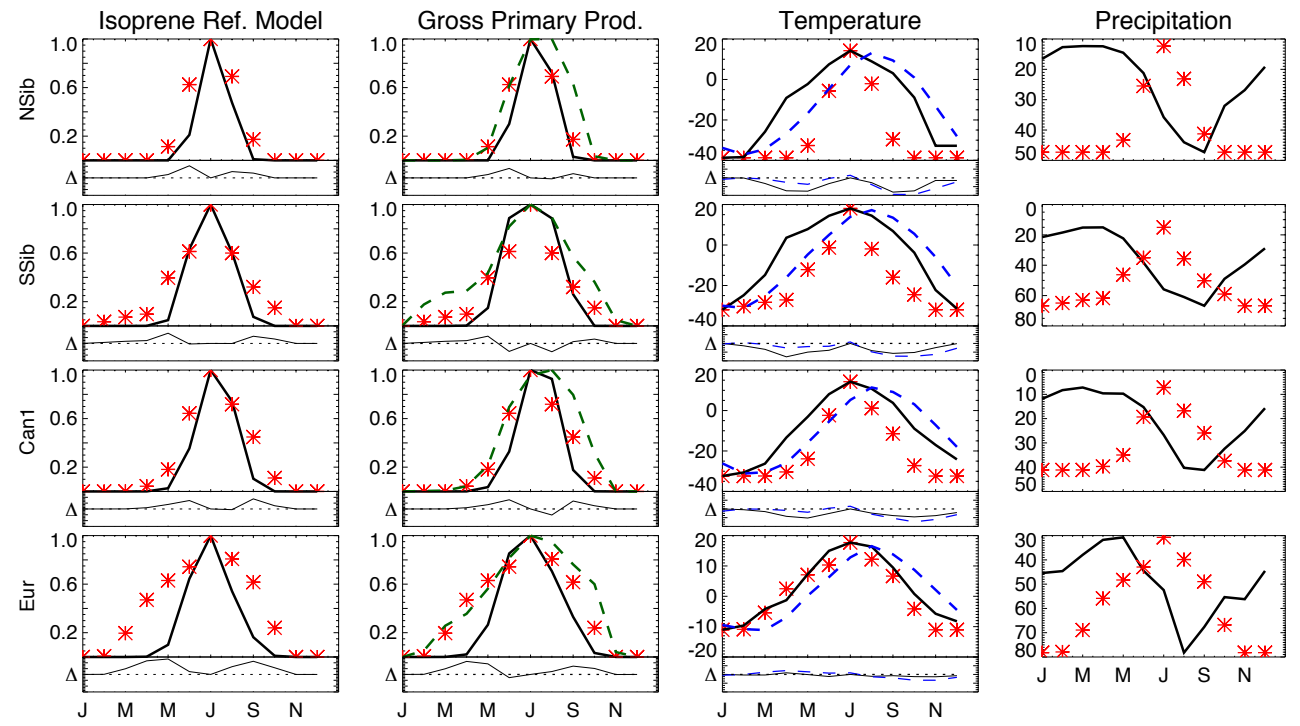

- Normalized $I_{R E F}$

$$
\begin{aligned}
& \text { - Normalized } \boldsymbol{G P P} \\
& \text { _ - fPAR }
\end{aligned}
$$

$-T_{C A N-L P J}$

- $\mathrm{T}_{\mathrm{AIR}}$

* * Formaldehyde scaled to main variable in plot

\subsection{TEMPERATE SITES}
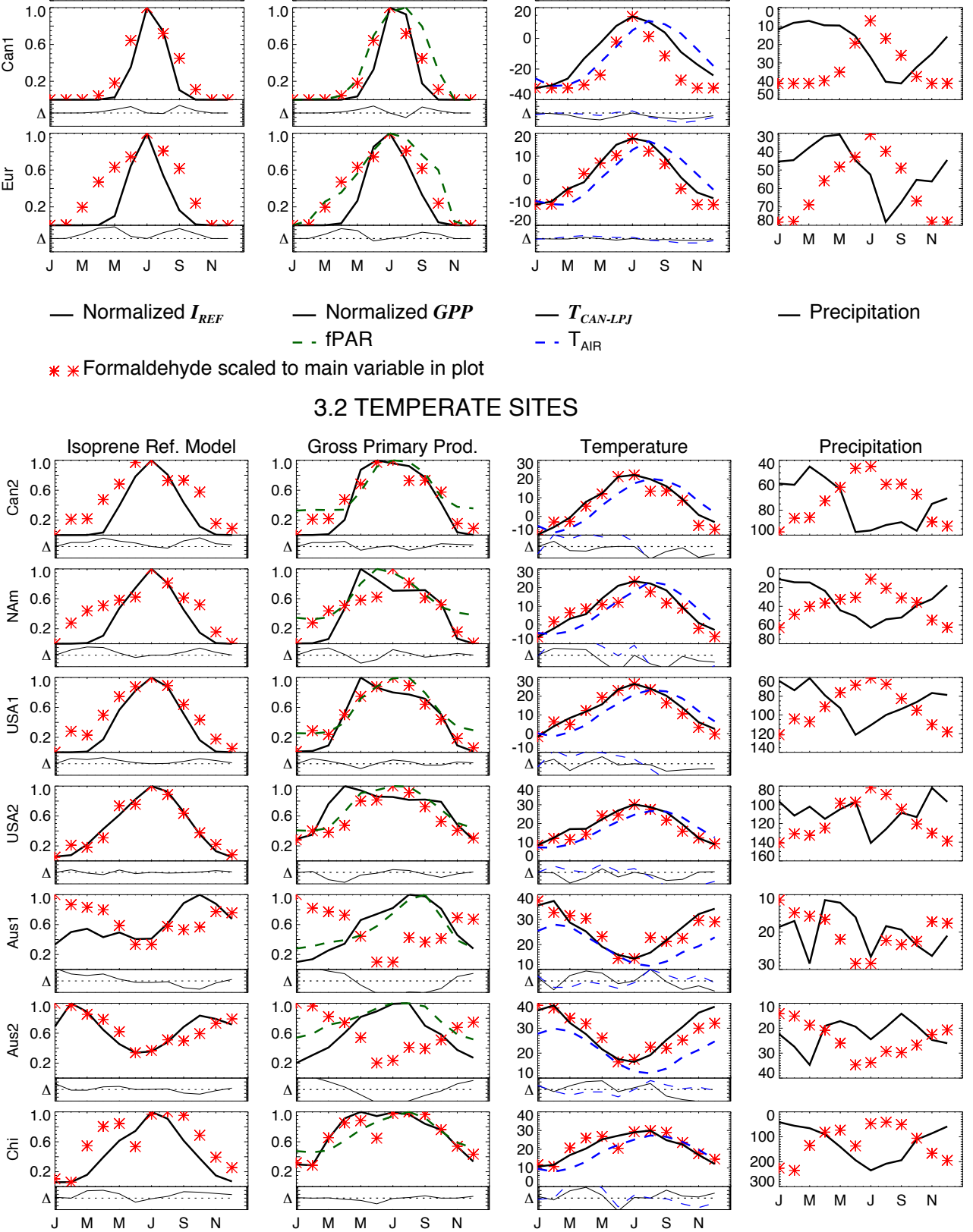

Figure 3. Mean seasonal cycles (1997-2006) for formaldehyde concentrations and potential environmental predictors. Regional and monthly averages are grouped into four panels: boreal regions, temperate regions, tropical forests and tropical savannas. In the first column, the mean seasonal cycle of the reference isoprene model, $I_{\mathrm{REF}}$, is shown as the solid line scaled to the maximum emission in that region; the mean seasonal cycle of the formaldehyde data is scaled to $I_{\mathrm{REF}}$, and plotted as red stars. Below each graph is shown the seasonal pattern of the difference between the formaldehyde data and $I_{\mathrm{REF}}(\Delta)$ to indicate potential seasonal biases. The second column shows the normalized mean seasonal GPP. The formaldehyde seasonal cycle is scaled to GPP and plotted as red stars. The mean seasonal cycle of fPAR is also shown (green dashed line). In the third column, the mean seasonal cycle of modelled canopy temperature ( $T_{\mathrm{CAN}-\mathrm{LPJ}}$, degreeC) and the formaldehyde data are shown as the solid line and red stars. The dashed blue line shows the observed air temperature. The panel below shows the difference between the formaldehyde cycle and the modelled canopy temperature as the solid line and formaldehyde minus $T_{\mathrm{AIR}}$ as the dashed blue line. The last column shows the mean seasonal cycle of regionally averaged precipitation, with an inverted $y$ axis. 


\subsection{TROPICAL FORESTS}
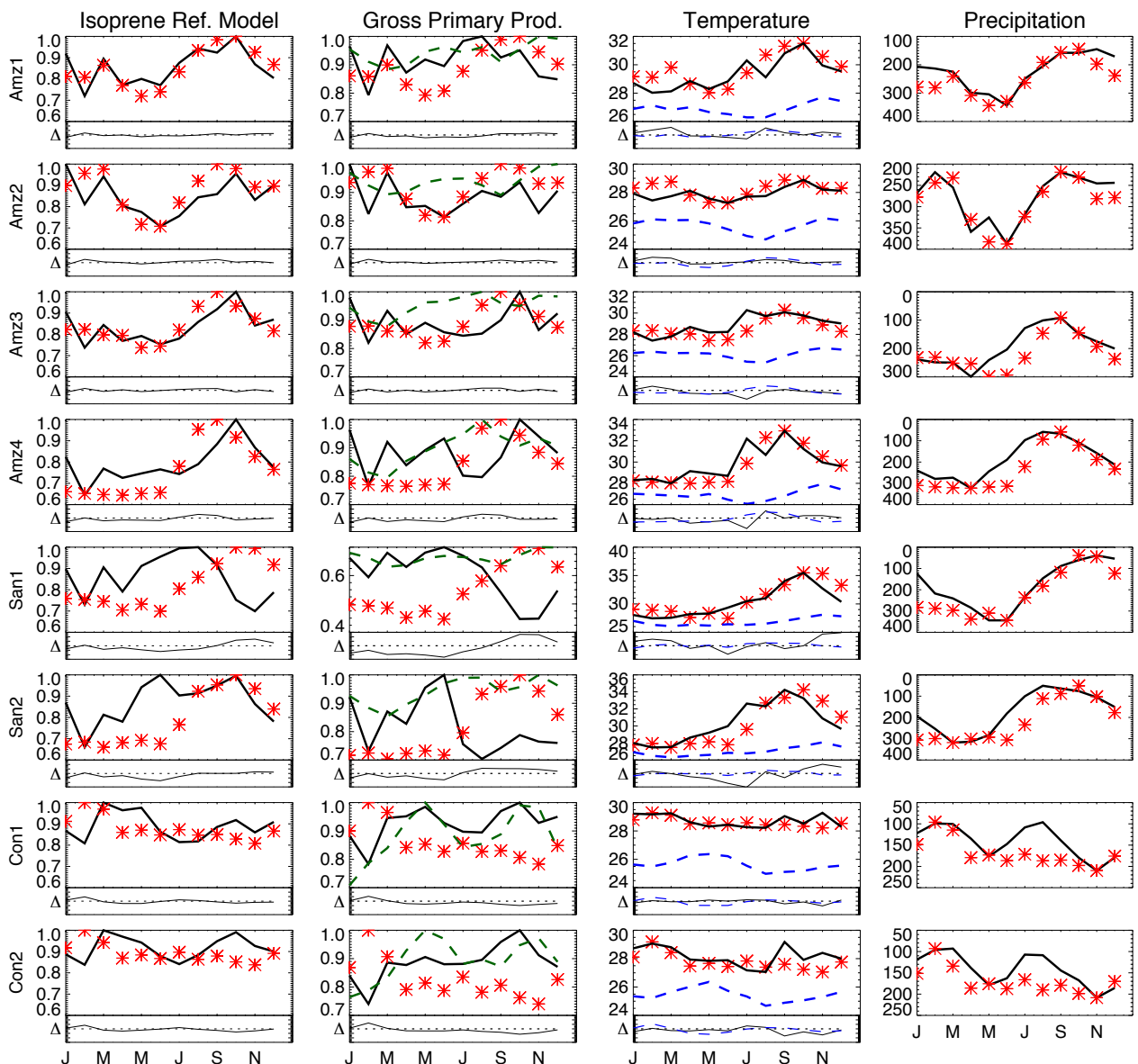

3.4 TROPICAL GRASS/WOOD LANDS
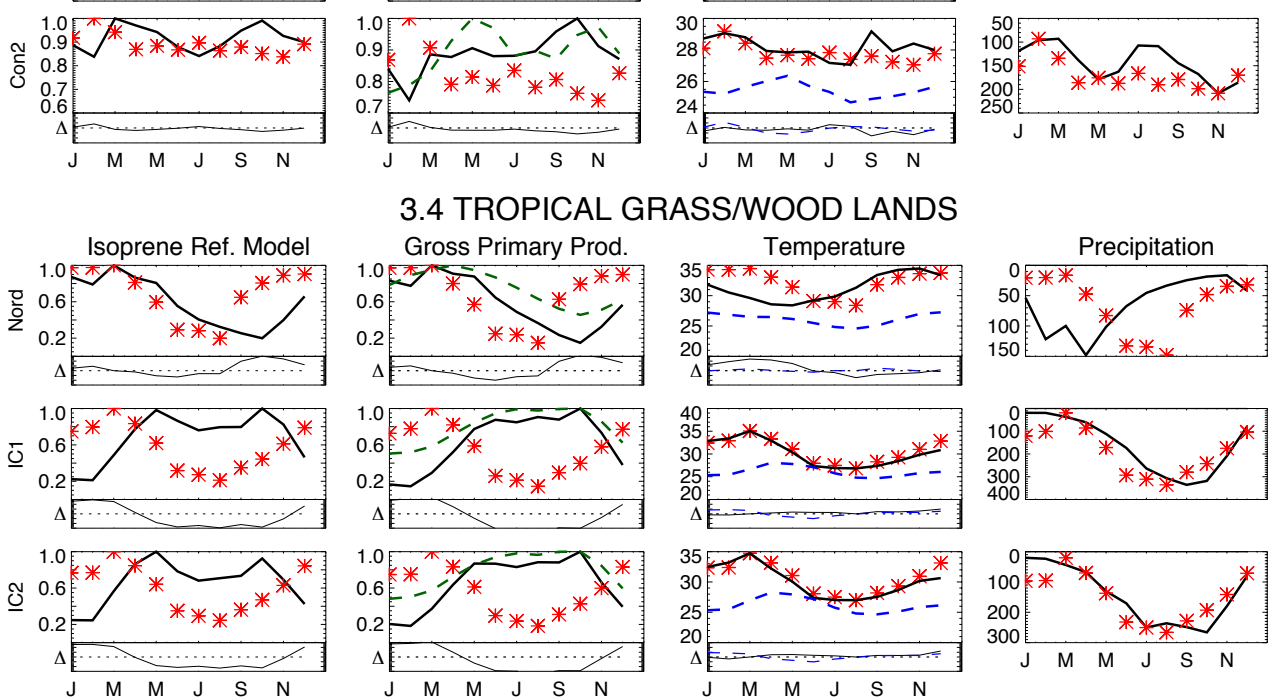

Figure 3. Continued.

Supplement shows the seasonal variation in $A$ in three latitude bands as modelled with TM5. In the tropics, $A$ showed a weak seasonal cycle that was distinct from the observed seasonal cycle of formaldehyde concentration (Fig. 3). In midlatitudes, $A$ was lowest and formaldehyde's chemical lifetime was shortest in summer, when observed formaldehyde concentration peaks (Fig. 3). In other words, atmospheric chemistry processes alone produce formaldehyde variations qualitatively different from (and frequently opposite to) those observed in both tropical and temperate latitudes. This reasoning justifies our identification of seasonal patterns in formaldehyde concentration to indicate seasonal patterns of isoprene emission. Note, however, that we focus our comparison strictly on the phase of the seasonal cycle and not on absolute concentration values, whose relationship to isoprene 
emission is expected to vary with latitude as shown in Supplement Fig. S1.

\subsection{Formaldehyde concentration data}

Formaldehyde concentration has been observed from space by the Global Ozone Monitoring Experiment (GOME) and SCanning Imaging Absorption SpectroMeter for Atmospheric CHartographY (SCIAMACHY) instruments. De Smedt et al. (2008) derived a coherent record combining the two satellite products. The data are total formaldehyde concentrations viewed along slanted atmospheric columns. De Smedt et al. (2008) analysed systematic and random errors in these measurements. Systematic errors include uncertainties in absorption cross sections and instrumental effects. The maximum error in the column estimates is about $45 \%$ at high latitudes, falling to $20 \%$ in tropical regions (de Smedt et al., 2008). Here, the effects of errors were reduced by taking regional averages.

\subsection{Choice of regions for analysis}

The selected regions (Fig. 2) represented a compromise: they had to be large enough to ensure minimal signal pollution from outside the region, but small enough to display a coherent seasonal cycle. As formaldehyde concentrations are elevated by biomass burning (Stavrakou et al., 2009), we selected regions outside areas with high biomass burning, defined here as being regions with a mean annual burnt fraction (van der Werf et al., 2010) less than 1\%. We relaxed the criterion for tropical savannas, thus including regions with $1 \%$ (Nord), $7 \%$ (IC1) and $9 \%$ (IC2) burnt fraction.

Transport from adjacent regions can influence the formaldehyde signal. Palmer et al. (2003) estimated the formaldehyde smearing length (over which any signal is attenuated by a factor $1 / e$ ) to be $\sim 50 \mathrm{~km}$. We used the smearing length to place a lower limit on region size, so that at least $50 \%$ of the signal should originate within the region. Two smearing lengths were adequate (the external signal will be attenuated by $1 / e^{2}$ ), so the region must be $>4.8$ times the smearing length, or $240 \mathrm{~km}$. All our regions were larger than this.

The regions sampled the major biomes including tundra (Can1, NSib), evergreen conifer forest (Eur), high-latitude deciduous forest (SSib), temperate grasslands (NAm), various combinations of mixed forest, crops and wooded grasslands (Can2, USA1, USA2, Chi), tropical grasslands or savannas (Nord, IC1, IC2), shrublands (Aus1, Aus2) and evergreen broadleaf forests (Amz 1-4, San1, San2, Con1, Con2). Deciduous broadleaf forests are included in USA1, but we could not find any region where they dominate that also satisfied all our other criteria. We grouped the regions for further analysis into boreal regions (NSib, SSib, Can1 and Eur), temperate regions (Can2, NAm, USA1, USA2, Aus1, Aus2 and Chi), tropical savannas (Nord, IC1 and IC2) and tropical forests (Amz 1-4, San1, San2, Con1, Con2).

\subsection{Observed predictor variables}

Isoprene emission has been observed to track air temperature in both short- and long-term experiments, but air temperature does not always predict well the field-measured seasonal cycle of isoprene emission in the tropics (Simon et al., 2005; Serca et al., 2001; Kuhn et al., 2004). Here we considered the air temperature, $T_{\mathrm{AIR}}$, and two measures of canopy temperature, $T_{\mathrm{CAN}-\mathrm{OBS}}$ (observed) and $T_{\mathrm{CAN}-\mathrm{LPJ}}$ (modelled). Gridded $T_{\mathrm{AIR}}$ data were obtained from the Climatic Research Unit (CRU) TS3.0 data set (http://badc.nerc. ac.uk/browse/badc/cru, Mitchell and Jones, 2005).The CRU data were also used for the mean seasonal cycle of precipitation, which is not considered as a candidate predictor variable but is helpful in explaining the inability of the standard variables to predict isoprene emission. $T_{\mathrm{CAN}-\mathrm{OBS}}$ is a remotely sensed "land-surface" temperature that records canopy temperature in densely vegetated regions (Wan, 2010). MODIS land-surface temperature data were obtained from http://neo. sci.gsfc.nasa.gov and are referred to as the Mod11C3 product. While MODIS temperatures are generally within $1{ }^{\circ} \mathrm{C}$ of in situ temperature measures, uncertainties in emissivities in arid and semi-arid regions may lead to larger errors in $T_{\mathrm{CAN}-\mathrm{OBS}}$ (Wan et al., 2010). fPAR represents the "greenness" of the land surface, i.e. absorption of (mainly red) light by chlorophyll. Its seasonal cycle at any latitude is therefore closely related to GPP. Remotely sensed fPAR measurements were obtained from the SeaWiFS satellite data archive (http: //oceancolor.gsfc.nasa.gov/SeaWiFS/, Gobron et al., 2006).

\subsection{Model-estimated predictor variables}

The Lund-Potsdam-Jena (LPJ) dynamic global vegetation model (Sitch et al., 2003; Gerten et al., 2004; Wania et al., 2009 ) was used to derive GPP, $T_{\mathrm{CAN}-\mathrm{LPJ}}$ and $I_{\mathrm{REF}}$. Observed (gridded) monthly air temperature $\left(T_{\mathrm{AIR}}\right)$, precipitation and fractional sunshine hours data, needed to drive LPJ, were obtained from the CRU TS3.0 data set. GPP for each plant functional type (PFT) is calculated in LPJ using a theoretically derived light-use efficiency formula based on the Collatz et al. (1991) version of the Farquhar et al. (1980) photosynthesis model, under the assumption of optimal nitrogen allocation through the canopy (Haxeltine and Prentice, 1996). Transpiration (required to estimate evaporative cooling) is calculated as the lesser of two rates: an energy-limited rate corresponding to atmospheric "demand", and a waterlimited rate representing "supply" - a plant-dependent maximum rate, reduced in proportion to soil moisture depletion. Canopy temperature for each PFT ( $\left.T_{\mathrm{CAN}-\mathrm{PFT}}\right)$ was calculated from the energy balance equation:

$T_{\mathrm{CAN}-\mathrm{PFT}}=T_{\mathrm{AIR}}+\frac{\operatorname{DRS}(1-\alpha)-\lambda E}{\rho c_{\mathrm{p}} / r_{\mathrm{b}, \mathrm{h}}+4 \sigma T_{\mathrm{AIR}}^{3}}$, 
where $T_{\mathrm{AIR}}$ is the mean air temperature; DRS is the mean downwelling shortwave radiation at the top of the canopy, estimated from insolation and fractional sunshine hours; $\alpha=$ 0.36 is the sum of the average broadband albedo and transmittance of leaves; $\lambda$ is the latent heat of vaporization of water; $E$ is modelled transpiration plus interception; $\rho$ is the density and $c_{\mathrm{p}}$ the specific heat capacity of air; $r_{\mathrm{b}, \mathrm{h}}$ is the boundary layer resistance to heat (set to $0.20 \mathrm{~s} \mathrm{~m}^{-1}$ for needle leaves and $0.025 \mathrm{~s} \mathrm{~m}^{-1}$ for other types of leaves, Kelliher et al 1993); and $\sigma$ is the Stefan-Boltzmann constant. Values of $T_{\mathrm{CAN}-\mathrm{PFT}}$ were averaged, weighted by their relative importance as indexed by each PFT's share of annual GPP, to determine the modelled canopy temperature, $T_{\mathrm{CAN}-\mathrm{LPJ}}$. Thus, more productive plant functional types influenced the composite $T_{\mathrm{CAN} \text {-LPJ }}$ more than less productive ones, but the seasonal cycle of GPP does not influence the seasonal cycle of $T_{\text {CAN-LPJ. }}$

\subsection{Reference isoprene model}

We used a representative process-based isoprene emission model to calculate $I_{\text {REF }}$ (see Supplement). Following Arneth et al. (2007), this model is based on the concept that isoprene emission is a fixed fraction of photosynthetic electron transport (Niinemets et al., 1999) multiplied by factors representing an inverse relationship to the leaf's internal $\mathrm{CO}_{2}$ concentration $\left(c_{\mathrm{i}}\right)$, and an exponential dependence on the modelled canopy temperature (called leaf temperature in Arneth et al., 2007). While the inverse relationship between isoprene emission and $\mathrm{CO}_{2}$ has been questioned (Sun et al., 2013), we maintain the $\mathrm{CO}_{2}$ dependency from Arneth et al. (2007) for consistency.

\subsection{Statistics and graphics}

Mean seasonal cycles of formaldehyde are shown for the 22 regions (Fig. 3) in four groups: boreal regions, temperate regions, tropical forests and tropical savannas. Normalized formaldehyde concentration in each region (red stars) was compared with the reference model $\left(I_{\mathrm{REF}}\right)$ in the first set of columns, with measures related to photosynthesis (fPAR and GPP) in the second set of columns, with temperature measures $\left(T_{\mathrm{AIR}}, T_{\mathrm{CAN}-\mathrm{OBS}}\right.$ and $\left.T_{\mathrm{CAN}-\mathrm{LPJ}}\right)$ in the third set of columns and precipitation in the final column. Pearson's correlations $(r)$ based on these plots are presented in Table 1 and Fig. 4.

\section{Results}

\subsection{Observed vs. modelled canopy temperatures}

Canopy and air temperature differ due to the balance of radiative heating, which is mainly driven by net radiation, and evaporative cooling. We compared the offsets between $T_{\mathrm{AIR}}$

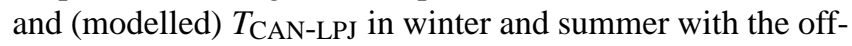

sets between $T_{\mathrm{AIR}}$ and (observed) $T_{\mathrm{CAN}-\mathrm{OBS}}$ (Supplement Fig. S1). Both observed and modelled canopy temperatures are commonly higher than air temperature, although evaporative cooling can dominate in some regions and seasons (e.g. in the USA2 region, and in boreal regions in winter). The large-scale patterns and magnitudes of the offsets are strikingly similar, although the remote-sensing data indicate greater cooling over the tropical rainforests.

\subsection{Performance of environmental predictors}

The reference model $\left(I_{\mathrm{REF}}\right)$ was successful in reproducing the seasonality of formaldehyde concentration at high latitudes $(r=0.91$ averaged over the boreal regions, $r=0.74$ over temperate regions), but not at low latitudes $(r=0.31$ over tropical forests, -0.16 over tropical savannas). GPP was strongly and positively correlated with formaldehyde concentration at high latitudes, but the correlation declined with decreasing latitude, reaching negative values in seven of the eleven tropical regions. All three temperature variables $\left(T_{\mathrm{AIR}}, T_{\mathrm{CAN}-\mathrm{OBS}}\right.$ and $\left.T_{\mathrm{CAN}-\mathrm{LPJ}}\right)$ were well correlated with formaldehyde concentration in high latitudes, but the correlations diverged at lower latitudes.

On average across all regions, $T_{\text {CAN-LPJ }}(r=0.80)$ and $T_{\text {CAN-OBS }}(r=0.85)$ provided much better predictive capability than air temperature $(r=0.56)$ and the reference model $(r=0.49)$, while GPP $(r=0.14)$ and fPAR $(r=0.25)$ had no predictive power. Only the observed and measured canopy temperatures showed significant relationships $(P<$ 0.05 ) to the seasonal cycle of formaldehyde concentration at all latitudes.

\subsubsection{Boreal regions}

The conclusions we can draw about isoprene's seasonal cycle are probably least well constrained in the boreal regions. Here the formaldehyde data can have errors as large as $45 \%$ (de Smedt et al., 2007), although this error is reduced during periods of strong sunlight - the growing season - and is further reduced by regional averaging. Furthermore, at least in some boreal ecosystems, monoterpenes may dominate the production of formaldehyde over the production via isoprene (Noe et al., 2012). Thus, while our $I_{\text {REF }}$, GPP and $T_{\text {CAN-LPJ }}$ all appear to predict the timing of maximum formaldehyde concentrations in boreal regions (Fig. 3, Table 1), the formaldehyde signal may not be entirely reflective of isoprene emission. Nonetheless, $T_{\text {CAN-LPJ }}(r=0.87)$ captured the formaldehyde timing better than $T_{\mathrm{AIR}}(r=0.73)$, peaking earlier in the season. $T_{\mathrm{CAN}-\mathrm{OBS}}$ also correlated highly with formaldehyde concentration $(r=0.95)$ in the boreal regions. The seasonal timings of canopy and air temperature in boreal regions differ because canopy temperature is related to the energy balance at the leaf surface and thus to insolation, which peaks in June. Air temperature does not peak until August, after a few months of summer sunshine 
Table 1. Correlations and $\mathrm{P}$ values of formaldehyde concentration with environmental predictor variables. Averages for each ecological zone are given and are labelled BOREAL (boreal regions), TEMP (temperate forests), TROP-F (tropical forests) and TROP-S (tropical savannas). The average of all sites is given as the last line of the table (ALL).

\begin{tabular}{|c|c|c|c|c|c|c|c|c|c|c|c|c|c|c|}
\hline & \multicolumn{7}{|c|}{ Correlation Coefficient, $r$} & \multicolumn{7}{|c|}{$p$ value } \\
\hline & \multirow[b]{2}{*}{$I_{\mathrm{REF}}$} & \multirow[b]{2}{*}{ GPP } & \multirow[b]{2}{*}{ fPAR } & \multirow[b]{2}{*}{ Prec } & \multirow[b]{2}{*}{$T_{\mathrm{AIR}}$} & \multicolumn{2}{|c|}{$\begin{array}{c}\text { Canopy } \\
\text { temp }\end{array}$} & \multirow[b]{2}{*}{$I_{\mathrm{REF}}$} & \multirow[b]{2}{*}{ GPP } & \multirow[b]{2}{*}{ fPAR } & \multirow[b]{2}{*}{ Prec } & \multirow[b]{2}{*}{$T_{\mathrm{AIR}}$} & \multicolumn{2}{|c|}{$\begin{array}{c}\text { Canopy } \\
\text { temp }\end{array}$} \\
\hline & & & & & & $T_{\mathrm{OBS}}$ & $T_{\mathrm{LPJ}}$ & & & & & & $T_{\mathrm{OBS}}$ & $T_{\mathrm{LPJ}}$ \\
\hline NSib & 0.93 & 0.95 & 0.88 & 0.53 & 0.68 & 0.93 & 0.78 & 0.00 & 0.00 & 0.00 & 1.00 & 0.00 & 0.00 & 0.00 \\
\hline SSib & 0.95 & 0.93 & 0.95 & 0.59 & 0.76 & 0.92 & 0.85 & 0.00 & 0.00 & 0.00 & 1.00 & 0.00 & 0.00 & 0.00 \\
\hline Can1 & 0.94 & 0.92 & 0.93 & 0.54 & 0.74 & 0.96 & 0.90 & 0.00 & 0.00 & 0.00 & 1.00 & 0.00 & 0.00 & 0.00 \\
\hline Eur & 0.83 & 0.89 & 0.91 & 0.26 & 0.72 & 0.98 & 0.97 & 0.00 & 0.00 & 0.00 & 0.98 & 0.00 & 0.00 & 0.00 \\
\hline BOREAL & 0.91 & 0.92 & 0.92 & 0.48 & 0.73 & 0.95 & 0.87 & 0.00 & 0.00 & 0.00 & 1.00 & 0.00 & 0.00 & 0.00 \\
\hline Can2 & 0.89 & 0.95 & 0.89 & 0.71 & 0.76 & 0.95 & 0.97 & 0.00 & 0.00 & 0.00 & 1.00 & 0.00 & 0.00 & 0.00 \\
\hline NAm & 0.87 & 0.81 & 0.82 & 0.85 & 0.73 & 0.94 & 0.93 & 0.00 & 0.00 & 0.00 & 1.00 & 0.00 & 0.00 & 0.00 \\
\hline USA1 & 0.96 & 0.93 & 0.95 & 0.89 & 0.74 & 0.94 & 0.97 & 0.00 & 0.00 & 0.00 & 1.00 & 0.00 & 0.00 & 0.00 \\
\hline USA2 & 0.98 & 0.70 & 0.97 & 0.64 & 0.80 & 0.89 & 0.96 & 0.00 & 0.00 & 0.00 & 1.00 & 0.00 & 0.00 & 0.00 \\
\hline Aus1 & -0.10 & -0.84 & -0.70 & -0.03 & 0.85 & 0.87 & 0.88 & 0.62 & 1.00 & 1.00 & 0.40 & 0.00 & 0.00 & 0.00 \\
\hline Aus2 & 0.76 & -0.89 & -0.87 & 0.50 & 0.93 & 0.86 & 0.88 & 0.00 & 1.00 & 1.00 & 1.00 & 0.00 & 0.00 & 0.00 \\
\hline Chi & 0.84 & 0.92 & 0.84 & 0.80 & 0.76 & 0.91 & 0.90 & 0.00 & 0.00 & 0.00 & 1.00 & 0.00 & 0.00 & 0.00 \\
\hline TEMP & 0.74 & 0.37 & 0.41 & 0.62 & 0.80 & 0.91 & 0.93 & 0.09 & 0.29 & 0.29 & 0.91 & 0.00 & 0.00 & 0.00 \\
\hline Amz1 & 0.77 & 0.26 & 0.15 & -0.87 & 0.28 & 0.93 & 0.75 & 0.00 & 0.20 & 0.31 & 0.00 & 0.18 & 0.00 & 0.00 \\
\hline Amz2 & 0.70 & 0.51 & -0.21 & -0.91 & 0.07 & 0.91 & 0.55 & 0.00 & 0.03 & 0.75 & 0.00 & 0.41 & 0.00 & 0.02 \\
\hline Amz3 & 0.69 & 0.21 & 0.25 & -0.76 & -0.11 & 0.95 & 0.68 & 0.00 & 0.25 & 0.20 & 0.00 & 0.63 & 0.00 & 0.00 \\
\hline Amz4 & 0.67 & -0.01 & 0.74 & -0.90 & 0.07 & 0.91 & 0.85 & 0.00 & 0.51 & 0.00 & 0.00 & 0.41 & 0.00 & 0.00 \\
\hline San1 & -0.40 & -0.91 & 0.48 & -0.89 & 0.85 & 0.90 & 0.88 & 0.92 & 1.00 & 0.04 & 0.00 & 0.00 & 0.00 & 0.00 \\
\hline San2 & 0.39 & -0.63 & 0.61 & -0.85 & 0.82 & 0.79 & 0.83 & 0.09 & 0.99 & 0.01 & 0.00 & 0.00 & 0.00 & 0.00 \\
\hline Con1 & 0.03 & -0.62 & -0.65 & -0.65 & 0.11 & 0.52 & 0.44 & 0.46 & 0.99 & 1.00 & 0.00 & 0.36 & 0.03 & 0.06 \\
\hline Con2 & -0.34 & -0.79 & -0.77 & -0.68 & 0.04 & 0.50 & 0.51 & 0.87 & 1.00 & 1.00 & 0.00 & 0.45 & 0.03 & 0.03 \\
\hline TROP-F & 0.31 & -0.25 & 0.08 & -0.81 & 0.27 & 0.80 & 0.68 & 0.29 & 0.62 & 0.41 & 0.00 & 0.31 & 0.01 & 0.01 \\
\hline Nord & 0.50 & 0.32 & 0.06 & 0.25 & 0.88 & 0.31 & 0.30 & 0.03 & 0.14 & 0.43 & 1.00 & 0.00 & 0.15 & 0.16 \\
\hline IC1 & -0.59 & -0.84 & -0.88 & -0.86 & 0.40 & 0.97 & 0.97 & 0.99 & 1.00 & 1.00 & 0.00 & 0.08 & 0.00 & 0.00 \\
\hline IC2 & -0.41 & -0.77 & -0.86 & -0.87 & 0.45 & 0.95 & 0.95 & 0.92 & 1.00 & 1.00 & 0.00 & 0.06 & 0.00 & 0.00 \\
\hline TROP-S & -0.16 & -0.43 & -0.56 & -0.50 & 0.58 & 0.75 & 0.74 & 0.65 & 0.71 & 0.81 & 0.33 & 0.05 & 0.05 & 0.05 \\
\hline ALL & 0.49 & 0.14 & 0.25 & -0.08 & 0.56 & 0.85 & 0.80 & 0.22 & 0.41 & 0.35 & 0.52 & 0.12 & 0.01 & 0.01 \\
\hline
\end{tabular}

have warmed the ground. GPP and the reference model show seasonal patterns closer to canopy temperature because GPP depends strongly on insolation and less strongly on air temperature.

\subsubsection{Temperate regions}

As in the boreal regions, the formaldehyde data can have large errors at temperate latitudes, although again these are reduced during sunny periods and by spatial averaging. Five of the seven temperate regions analysed showed similar correlation patterns to the boreal regions. Can2, NAm, USA1, USA2 and Chi showed strong correlations with formaldehyde for GPP, $I_{\mathrm{REF}}$ and the three temperatures variables, averaging, in increasing order: $r=0.75\left(T_{\mathrm{AIR}}\right), 0.85(\mathrm{GPP})$,
$0.85\left(I_{\mathrm{REF}}\right), 0.92\left(T_{\mathrm{CAN}-\mathrm{OBS}}\right)$ and $0.94\left(T_{\mathrm{CAN}-\mathrm{LPJ}}\right)$. For these regions, temperature (air or canopy), GPP and the reference model all provided reasonable predictive power for isoprene emission, as was concluded by Palmer et al. (2006) for North America. However, even in these temperate locations, canopy temperature (whether observed or modelled) predicted isoprene emission better than air temperature, GPP or the reference model.

By contrast, in the temperate dry grassland and shrubland regions of Australia, Aus1 and Aus2, GPP was negatively correlated ( $r=-0.84,-0.89$, respectively), while canopy $(r$ observed $=0.87,0.86$; modelled $=0.88,0.88)$ and air temperatures $(r=0.85$ and 0.93$)$ were positively correlated, with formaldehyde concentration. Unlike in the other 


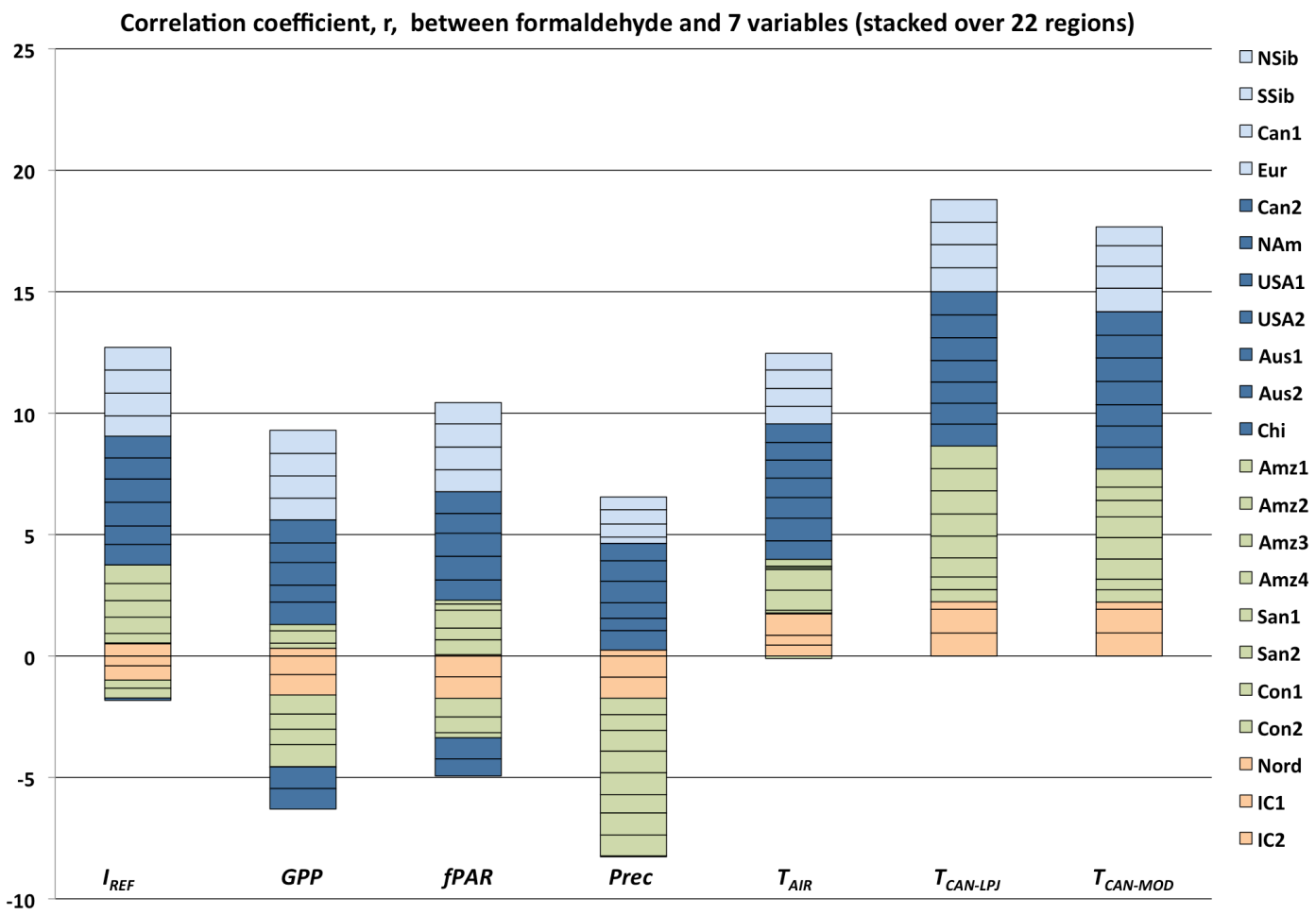

Figure 4. Correlations of the mean seasonal cycle of formaldehyde concentration with potential environmental predictors, shown as stacks of boxes, with one box for each region. If each region had $r=1$ the bar would reach a height of 22 . The boxes are colour-coded by ecological zone: boreal $=$ light blue; temperate $=$ dark blue; tropical forests $=$ green; tropical savannas $=$ orange. The first column represents the correlation between the mean seasonal cycle of formaldehyde and the mean seasonal cycle of the reference model, $I_{\mathrm{REF}}$. Subsequent columns show the correlation of the mean seasonal cycle of formaldehyde with the mean seasonal cycles of gross primary production (GPP) from the LPJ model, the fraction of absorbed photosynthetically active radiation (fPAR) from SeaWiFS satellite data, precipitation (Prec) and air temperature $\left(T_{\mathrm{AIR}}\right)$ from CRU data, canopy temperature $\left(T_{\mathrm{CAN}-\mathrm{LPJ}}\right)$ modelled using LPJ and canopy temperature $\left(T_{\mathrm{CAN}-\mathrm{OBS}}\right)$ from the MODIS land-surface temperature observations.

temperate regions and the boreal regions, the seasonality of GPP in these dry mid-latitude ecosystems was not in synchrony with the temperature cycle, allowing distinct responses of isoprene emission to GPP and temperature. The temperature effect dominates. This finding suggests that the success of GPP in predicting isoprene emission at boreal sites and wetter temperate sites might be solely due to coincidence in the timing of peaks in leaf temperature and photosynthetic rates.

\subsubsection{Tropical regions}

In the tropical regions, GPP entirely failed to predict the seasonal cycle of formaldehyde concentration. The mean correlation coefficient for GPP versus formaldehyde concentration in the tropical forest regions was $r=-0.25$. The reference model $(r=0.31)$ and $\mathrm{T}_{\mathrm{AIR}}(r=0.27)$ performed better, and across the four Amazon sites, the reference model achieved $r=0.71$. This is larger than was found by Barkley et al. (2008) over Amazonia using a similar model $(r=0.41)$ (perhaps because we used canopy temperature rather than air temperature in our reference model). Nonetheless, observed and modelled canopy temperature were once again the best predictors: $r=0.80$ for $T_{\mathrm{CAN}-\mathrm{OBS}}$ in forests and $r=0.85$ in savannas; $r=0.68$ for $T_{\mathrm{CAN}-\mathrm{LPJ}}$ in forests and $r=0.74$ in savannas. Other predictors performed poorly: $r=0.31$ for the reference model across all tropical forests and $r=-0.16$ for savannas; $r=0.27$ for $T_{\mathrm{AIR}}$ in forests and $r=0.58$ in savannas; $r=-0.25$ for GPP in forests and $r=-0.43$ in savannas. See below for a discussion of how the fPAR results strengthen these conclusions. To further test the statistical significance of these findings, we also report the $p$ values of these correlations in Table 1 . The $p$ value for correlation of formaldehyde with both the observed and the modelled canopy temperature was less than (or equal to) 0.05 for all the sites except Nordeste. In Nordeste the $p$ value was 0.16 , and correspondingly it was the site with the lowest $r$ between the canopy temperatures and formaldehyde. Therefore at 21 out of 22 sites we can reject the null hypothesis that formaldehyde is not correlated to either modelled or observed canopy temperature. At the other extreme, high $p$ values $(p>0.90)$ were found at eight sites for GPP and six sites for fPAR including temperate and tropical grasslands 
and tropical forests, implying that we cannot reject the null hypothesis that formaldehyde is uncorrelated with GPP or fPAR. For comparisons against all variables except precipitation, $p>0.05$ corresponds with $r<0.50$. The $p$ values thus confirm our conclusion that the seasonality of formaldehyde is linked to canopy temperature and not to GPP or fPAR.

In all of the tropical regions studied, formaldehyde concentration peaked during the season of lowest precipitation (Fig. 3), with the exception of the second dry season in the Congo basin. This is opposite to the pattern of GPP. GPP was especially low during long periods of drought, as in Santarem (San1) and the Ivory Coast (IC1 and IC2). Isoprene emission increases at the same time as canopy temperature rises, and not as the photosynthesis rate falls. During the dry season, stomata are closed and GPP is reduced, but leaf temperatures are correspondingly high as evaporative cooling is suppressed. We infer that isoprene emissions in the tropics represents a response to high leaf temperatures and not to GPP.

\subsection{Global summary}

Average correlations between observed canopy temperature and formaldehyde concentration are relatively high through all ecological zones $(0.95,0.91,0.80,0.75$ for boreal, temperate, tropical forest and savanna regions). Correlations for modelled canopy temperature are also relatively high $(0.87$, $0.93,0.68,0.74)$. Correlations for both observed and modelled canopy temperature exceed those for air temperature $(0.73,0.80,0.27,0.58)$. The steep fall in the average correlation of GPP with formaldehyde concentration from high to low latitudes $(0.92,0.41,0.08,-0.56)$ suggests, as the most parsimonious explanation, that GPP is not a control on the seasonality of isoprene emission while the correlation in boreal forest is caused by the similar seasonality of GPP and canopy temperature, both peaking in summer.

For completeness, we also include the correlation of formaldehyde with precipitation. In tropical forests, lack of rainfall ( $r=-0.81$ ) was found to predict isoprene emission as well as observed canopy temperature; likewise for the two non-Nordeste tropical grasslands. Rainfall $(r=0.80)$ was a moderately good predictor of formaldehyde in temperate regions $(r=0.80)$, but less so in boreal regions $(r=0.48)$. The switch in sign between tropics and extratropics suggests that precipitation is not a causative factor.

To exclude the possibility that the poor performance of GPP and the reference model as predictors of formaldehyde concentration in the tropics was caused by errors in the model, we explored the correlation of a directly observed variable (fPAR) whose close relationship to GPP is commonly exploited in satellite-based modelling of primary production (e.g. Zhao and Running, 2010). Figure 3 shows close correspondence between the seasonal cycles of observed fPAR and modelled GPP, with a few exceptions among tropical forests (e.g. Amz4 and San1). But neither GPP nor fPAR consistently tracks formaldehyde concentration. The average correlation between fPAR and formaldehyde concentration was only 0.08 in tropical forests. In the tropical savannas (IC1, IC2) and temperate grasslands (Aus1, Aus2), GPP and fPAR had similar seasonal cycles, and both had negative correlations with formaldehyde. Only in the temperate forests and boreal regions did GPP and fPAR achieve $r>0.75$, and even in these regions, the mean correlation of $T_{\mathrm{CAN}-\mathrm{OBS}}$ with formaldehyde concentration was greater than the correlation of GPP or fPAR with formaldehyde concentration in eight out of the eleven regions. The same held for $T_{\text {CAN-LPJ }}$ in seven out of the eleven regions.

We present these results graphically in Fig. 4, where each column represents the correlation of the mean seasonal cycle of the relevant variable vs. formaldehyde in all the regions. Correlations are stacked vertically, so that if all regions showed perfect agreement $(r=1)$, the stack would reach a height of 22 units. Figure 4 highlights the lack of a consistent relationship between GPP (or fPAR) and formaldehyde concentration. High formaldehyde concentrations are associated with low rainfall in the tropics, but not in temperate regions. In contrast, the modelled and observed canopy temperatures capture the seasonality of formaldehyde concentration (average $r=0.80$ and 0.85 , respectively) at all latitudes. These findings strongly suggest that isoprene emission varies over the seasonal cycle in response to seasonal variations in canopy temperature, independently of canopy photosynthesis.

\section{Discussion and conclusions}

The inference that canopy temperature drives seasonal isoprene cycles is supported most strongly for the tropics, where most isoprene emission occurs (Sharkey et al., 2008) and where previous models have struggled to capture the seasonal cycle (Barkley et al., 2007; Kuhn et al., 2004). At high latitudes, the formaldehyde data has larger errors (de Smedt et al., 2008), and in boreal regions can be influenced by nonisoprene precursors (Noe et al., 2012). Strikingly, it is in the tropics that our analysis shows a major phase difference between the seasonal cycles of GPP and those of canopy temperatures and the formaldehyde signal. In the temperate and boreal regions, satellite data errors can reach as high as $45 \%$ for individual observations (de Smedt et al., 2008) but these errors are mitigated here by area-averaging and by the fact that the data are most reliable in summer, when most isoprene emission occurs. Canopy temperature remains the best predictor of formaldehyde in temperate and boreal regions. We therefore suggest that it is likely to be the dominant control in these regions, as well as in the tropics.

Experimental evidence is accumulating that isoprene emission protects leaves against both oxidative damage and high temperatures (Sharkey and Yeh, 2001; Sasaki et al., 2007; Sharkey et al., 2008; Vickers et al., 2009; Behnke et al., 2010). It has been argued that these two processes are 
not unrelated - protection against heat stress requires protection against reactive oxygen species, which are released in response to heat damage (Jardine et al., 2011; Vickers et al., 2009; Velikova and Loreto, 2005). Other studies have shown that isoprene emissions increase the thermal stability of thylakoids at high temperatures (Siwko et al., 2007; Velikova et al., 2011). It is to be expected that the environmental controls of isoprene emission would relate to its adaptive significance. For example, an effect of temperature on isoprene synthase transcription might promote thermoprotection at high temperatures, by allowing a steeper response to temperature than would be expected solely due to the kinetics of the synthesis pathway (Li et al., 2011). These arguments suggest that we might expect isoprene emission under natural conditions to be finely tuned to leaf temperature.

The finding that the seasonal cycle of isoprene is uncorrelated with primary production is perhaps not surprising because although isoprene is constructed from carbon chains produced by photosynthesis, it is emitted at rates three orders of magnitude less than carbon fixation. Therefore, although isoprene emission clearly requires some productivity and some leaves to be present, our results imply that the seasonality of isoprene emission is decoupled from the seasonality of primary productivity. A recent analysis of the various known environmental dependences of isoprene emission points to a common mechanism whereby the rate of emission is proportional to the difference between the rate at which reducing power is generated by PhotoSystem II, and the ability of the chloroplasts to utilize this reducing power for carbon fixation (Morfopoulos et al., 2013). According to this mechanism, we would not expect a close coupling between GPP and isoprene emission. Indeed, under some circumstances, such as drought or low ambient $\mathrm{CO}_{2}$ concentration, this mechanism predicts that isoprene emission should increase as GPP declines. Previous observations on leaves (Sharkey et al., 1999; Pétron et al., 2001) and canopies (Fuentes et al., 1999; Fuentes and Wang, 1999) have also shown that long-term isoprene emission tracks growth temperature. Positive effects of high temperature may include enzyme kinetic responses, effective immediately, and further effects on the transcript level of key enzymes (Li et al., 2011; Harrison et al., 2013), which remain to be systematically explored. Thus, our empirical findings are consistent with current understanding of the controls of isoprene biosynthesis, and suggest possible avenues for the exploration of how field-scale emissions could be predicted from a unified approach to isoprene modelling.

All current large-scale models for isoprene emission recognize the dependence of isoprene synthesis on photosynthetic electron transport - either explicitly, or implicitly through light-response functions. Current models also all include temperature effects, and some explicitly include antecedent temperature conditioning as well (Guenther et al., 1999). Our results suggest, however, that current models may not capture the overriding dominance of canopy tempera- ture as a predictor of the seasonal cycle of isoprene emission, especially in the tropics. Our results also imply that the explicit modelling of canopy temperature will be an important component of next-generation models. Remotely sensed observations allow a regional analysis intermediate between the global scale of interest in the relationship between atmospheric chemistry and climate, and the more local scale of direct emission measurements. Thus, they provide a rich source of empirical information for the development, improvement and evaluation of models. The clear empirical relationship we have shown between canopy temperature and isoprene emission should represent a benchmark to be met by models.

\section{The Supplement related to this article is available online at doi:10.5194/bg-11-3437-2014-supplement.}

Acknowledgements. This work was supported by EU-Project HYMN (GOCE-037048). We thank Josh Fisher for supplying the fPAR data. C. Morfopoulos received funding from the European Community's Seventh Framework Programme (FP7 2007-2013) under grant agreement 238366 (GREENCYCLES II). Also, we thank the reviewers and editor who provided thoughtful and constructive comments to improve the quality of the paper.

Edited by: G. Wohlfahrt

\section{References}

Abbot, D. S., Palmer, P. I., Martin, R. V., Chance, K. V., Jacob, D. J., and Guenther, A.: Seasonal and interannual variability of North American isoprene emissions as determined by formaldehyde column measurements from space, Geophys. Res. Lett., 30, 1886, doi:10.1029/2003GL017336, 2003.

Alton, P. B.: Reduced carbon sequestration in terrestrial ecosystems under overcast skies compared to clear skies, Agri. Forest Meteorol., 148, 1641-1653, 2008.

Arneth, A., Niinemets, Ü., Pressley, S., Bäck, J., Hari, P., Karl, T., Noe, S., Prentice, I. C., Serça, D., Hickler, T., Wolf, A., and Smith, B.: Process-based estimates of terrestrial ecosystem isoprene emissions: incorporating the effects of a direct $\mathrm{CO}_{2}$-isoprene interaction, Atmos. Chem. Phys., 7, 31-53, doi:10.5194/acp-7-31-2007, 2007.

Barkley, M. P., Palmer, P. I., Kuhn, U., Kesselmeier, J., Chance, K., Kurosu, T. P., Martin, R. V., Helmig, D., and Guenther, A.: Net ecosystem fluxes of isoprene over tropical South America inferred from Global Ozone Monitoring Experiment (GOME) observations of formaldehyde columns, J. Geophys. Res., 113, D20304, doi:10.1029/2008JD009863, 2008.

Behnke, K., Loivamäki, M., Zimmer, I., Rennenberg, H., Schnitzler, J.-P., and Louis, S.: Isoprene emission protects photosynthesis in sunfleck exposed Grey poplar, Photosynth. Res., 104, 5-17, 2010.

Collatz, G. J., Ball, J. T., Grivet, C., and Barry, J. A.: Physiological and environmental regulation of stomatal conductance, photosynthesis and transpiration: a model that includes a laminar boundary layer, Agr. Forest Meteorol., 54, 107-136, 1991. 
Collins, W. J., Derwent, R. G., Johnson, C. E., and Stevenson, D. S.: The oxidation of organic compounds in the troposphere and their global warming potential, Clim. Change, 52, 453-479, 2001.

deFries, R. S. and Townshend, J. R. G.: NDVI-derived land cover classifications at a global scale, Int. J. Remote Sens., 15, 35673586, 1994.

De Smedt, I., Müller, J.-F., Stavrakou, T., van der A, R., Eskes, H., and Van Roozendael, M.: Twelve years of global observations of formaldehyde in the troposphere using GOME and SCIAMACHY sensors, Atmos. Chem. Phys., 8, 4947-4963, doi:10.5194/acp-8-4947-2008, 2008.

Farquhar, G. D., von Caemmerer, S., and Berry, J. A.: Modelling of photosynthetic response to environmental conditions, in: Physiological Plant Ecology II: Water Relations and Carbon Assimilation, edited by: Nobel, P. S., Osmond, C. B., and Ziegler, H., Springer, Berlin, 549-587, 1980

Fu, T.-M., Jacob, D. J., Palmer, P. I., Chance, K.,Wang, Y. X., Barletta, B., Blake, D. R., Stanton, J. C., and Pilling, M. J.: Spacebased formaldehyde measurements as constraints on volatile organic compound emissions in East and South Asia, J. Geophys. Res., 112, D06312, doi:10.1029/2006JD007853, 2007.

Fuentes, J. D. and Wang, D.: On the seasonality of isoprene emission from a mixed temperate forest, Ecol. Appl., 9, 1118-1131, 1999.

Fuentes, J. D., Wang, D., and Gu, L.: Seasonality variations in isoprene emissions from a boreal aspen forest, J. Appl. Meteorol., 38, 855-869, 1999.

Gerten, D., Schaphoff, S., Haberlandt, U., Lucht, W., and Sitch, S.: Terrestrial vegetation and water balance - hydrological evaluation of a dynamic global vegetation model, J. Hydrol., 286, 249270, 2004.

Gobron, N., Pinty, B., Aussedat, O., Chen, J. M., Cohen, W. B., Fensholt, R., Gond, V., Huemmrich, K. F., Lavergne, T., Mélin, F., Privette J. L., Sandholt, I., Taberner, M., Turner, D. P., Verstraete, M. M., and Widlowski, J. L.: Evaluation of fraction of absorbed photosynthetically active radiation products for different canopy radiation transfer regimes: Methodology and results using Joint Research Center products derived from SeaWiFS against ground-based estimations, J. Geophys. Res., 111, D13110, doi:10.1029/2005JD006511, 2006.

Guenther, A., Zimmerman, P. R., Harley, P. C., Monson, R. K., and Fall, R.: Isoprene and monoterpene emission rate variability: Model evaluations and sensitivity analyses, J. Geophys. Res., 98, 12609-12617, 1993.

Guenther, A., Baugh, B., Brasseur, G., Greenburg, J., Harley, P., Klinger, L., Serça, D., and Vierling, L.: Isoprene emission estimates and uncertainties for the Central African EXPRESSO study domain, J. Geophys. Res., 104, 30625-30639, 1999.

Guenther, A., Karl, T., Harley, P., Wiedinmyer, C., Palmer, P. I., and Geron, C.: Estimates of global terrestrial isoprene emissions using MEGAN (Model of Emissions of Gases and Aerosols from Nature), Atmos. Chem. Phys., 6, 3181-3210, doi:10.5194/acp-63181-2006, 2006.

Harrison, S. P., Morfopoulos, C., Srikanta Dani, K. G., Prentice, I. C., Arneth, A., Atwell, B. J., Barkley, M. P., Leishman, M. R., Loreto, F., Medlyn, B. E., Niinemets, Ü., Possell, M., Peñuelas, J., and Wright,I. J.: Volatile isoprenoid emissions from plastid to planet, New Phytol., 197, 49-57, 2013.
Haxeltine, A. and Prentice, I. C.: A general model for the lightuse efficiency of primary production, Funct. Ecol., 10, 551-561, 1996.

Heald, C. L., Henze, D. K., Horowitz L. W., Feddema J., Lamrque, J.-F., Guenther, A., Hess, P. G., Vitt, F., Seinfeld, J. F., Goldstein, A. H., andFung, I.: Predicted change in global secondary organic aerosol concentrations in response to future climate, emissions and land use change, J. Geophys. Res., 113, 1127-1140, 2009.

Huijnen, V., Williams J. , van Weele M., van Noije, T., Krol, M., Dentener, F., Segers, A., Houweling S., Peters W., de Laat J., Boersma, F., Bergamaschi, P., van Velthoven, P., Le Sager, P., Eskes, H., Alkemade, F., Scheele, R., Nédélec, P., and Pätz, H.-W.: The global chemistry transport model TM5: description and evaluation of the tropospheric chemistry version 3.0., Geosci. Model Develop., 3, 445-473, 2010.

Jardine, K. J., Monson, R. K., Abrell, L., Saleska, S. R., Arneth, A., Jardine, A., Ishida, A. Y., Serrano A. M. Y., Artaxo, P., Karl, T., Fares, S., Goldstein, A., Loreto, F., and Huxman, T.: Within-plant isoprene oxidation confirmed by direct emissions of oxidation products methyl vinyl ketone and methacrolein, Glob. Change Biol., 18, 973-984, doi:10.1111/j.1365-2486.2011.02610x, 2011.

Kelliher, F. M., Leuning, R., and Schulze, D.: Evaporation and canopy characteristics of coniferous forests and grasslands, Oecologia, 93, 153-163, 1993.

Kuhn, U., Rottenberger, S., Biesenthal, T., Wolf, A., Schebeske, G., Ciccioli, P., Brancaleoni, E., Frattoni, M., Tavares, T. M., and Kesselmeier, J.: Seasonal differences in isoprene and lightdepdendent monoterpene emission by Amazonian tree species, Glob. Change Biol., 10, 663-682, 2004.

Laothawornkitkul, J., Taylor, J. E., Paul, N. D., and Hewitt, C. N.: Biogenic volatile organic compounds in the Earth system, New Phytol., 183, 27-51, 2009.

Li, Z., Ratliff, E. A., and Sharkey, T. D.: Effect of temperature on postillumination isoprene emission in oak and poplar, Plant Physiol., 155, 1037-1046, 2011.

Marais, E. A., Jacob, D. J., Kurosu, T. P., Chance, K., Murphy, J. G., Reeves, C., Mills, G., Casadio, S., Millet, D. B., Barkley, M. P., Paulot, F., and Mao, J.: Isoprene emissions in Africa inferred from OMI observations of formaldehyde columns, Atmos. Chem. Phys., 12, 6219-6235, doi:10.5194/acp-12-62192012, 2012.

Millet, D. B., Jacob, D. J., Boersma, K. F., Fu, T.-M., Kurosu, T. P., Change, K., Heald, C. L., and Guenther, A.: Spatial distribution of isoprene emissions from North America derived from formaldehyde column measurements by the OMI satellite sensor, J. Geophys. Res., 113, D02307, doi:10.1029/2007JD008950, 2008.

Mitchell, T. and Jones, C. D.: An improved method of constructing a database of monthly climate observations and associated highresolution grid, Int. J. Climatol., 25, 693-712, 2005.

Monson, R. K., Trahan, N., Rosentiel, T. N., Veres, P., Moore, D., Wilkinson, M., Norby, R. J., Volder, A., Tjoelker, M. G., Broske, D. D., Karnosky, D. F., and Fall, R.: Isoprene emission from terrestrial ecosystems in response to global change: minding the gap between models and observations, Philos. T. R. Soc. A, 365, 1677-1695, 2007. 
Monson, R. K., Grote, R., Niinemets, Ü., and Schnitzler, J.-P.: Modeling the isoprene emission rate from leaves, New Phytol., 195, 541-559, 2012.

Morfopoulos, C., Prentice, I. C., Keenan, T. R., Friedlingstein, P., Medlyn, B. E., and Possell, M.: A unifying conceptual model for the environmental responses of isoprene emission by plants, Ann. Bot.-London, 112, 1223-1238, doi:10.1093/aob/mct206, 2013.

Niinemets, Ü., Tenhunen, J. D., Harley, P. C., and Steinbrecher, R.: A model of isoprene emission based on energetic requirements for isoprene synthesis and leaf photosynthetic properties for Liquidamber and Quercus, Plant Cell Environ., 22, 13191335, 1999.

Noe, S. M., Hüve, K., Niinemets, Ü., and Copolovici, L.: Seasonal variation in vertical volatile compounds air concentrations within a remote hemiboreal mixed forest, Atmos. Chem. Phys., 12, 3909-3926, doi:10.5194/acp-12-3909-2012, 2012.

Pacifico, F., Harrison, S. P., Jones, C. D., Arneth, A., Sitch, S., Weedon, G. P., Barkley, M. P., Palmer, P. I., Serça, D., Potosnak, M., $\mathrm{Fu}, \mathrm{T}$.-M., Goldstein, A., Bai, J., and Schurgers, G.: Evaluation of a photosynthesis-based biogenic isoprene emission scheme in JULES and simulation of isoprene emissions under presentday climate conditions, Atmos. Chem. Phys., 11, 4371-4389, doi:10.5194/acp-11-4371-2011, 2011.

Palmer, P. I., Jacob, D. J., Fiore, A. M., and Martin, R. V.: Mapping isoprene emissions over North America using formaldehyde column observations from space, J. Geophys. Res., 108, 1-47, 2003.

Palmer, P. I., Abbot, D. S., Fu, T.-M., Jacob, D. J., Chance, K., Kurosu, T. P., Guenther, A., Wiedinmyer, C., Stanton, J. C., Pilling, M. J., Pressley, S. N., Lame, B., and Sumner, B. L.: Quantifying the seasonal and interannual variability of North American isoprene emissions using satellite observations of the formaldehyde column, J. Geophys. Res., 111, D12315, doi:10.1029/2005JD006689, 2006.

Peñuelas, J. and Staudt, M.: BVOCs and global change, Trends Plant Sci., 15, 133-144, 2010.

Pétron, G., Harley, P., Greenberg, J., and Guenther, A.: Seasonal temperature variations influence isoprene emission, Geophys. Res. Lett., 28, 1707-1710, 2001.

Possell, M., Nicholar Hewitt, C., and Beerling, D. J.: The effects of glacial atmospheric $\mathrm{CO}_{2}$ concentrations and climate on isoprene emissions by vascular plants, Glob. Change Biol., 11, 6069, 2005.

Ruimy, A., Jarvis, P. G., Baldocchi, D. D., Saugier, B., and Valentini, R.: $\mathrm{CO}_{2}$ fluxes over plant canopies: a review, Adv. Ecol. Res., 26, 2-68, 1995.

Sasaki, K., Saito, T., Lämsä, M., Oksman-Caldentey, K.-M., Suzuki, M., Ohyama, K. Muranaka, T., Ohara, K., and Yazaki, K.: Plants utilize isoprene emission as a thermotolerance mechanism, Plant Cell Physiol., 48, 1254-1262, 2007.

Serça, D., Guenther, A., Klinger, L., Vierling, L., Harley, P., Druilhet, A., Greenberg, J., Baker, B., Baugh, W., Bouka-Biona, C., Loemba-Ndembi, J.: EXPRESSO flux measurements at upland and lowland Congo tropical forest site, Tellus B, 53, 220-234, 2001.

Sharkey, T. D. and Yeh, S.: Isoprene emission from plants. Annu. Rev. Plant Biol., 52, 407-436, 2001.

Sharkey, T. D., Singsaas, E. L., Lerdau, M. T., and Geron, C.: Weather effects on isoprene emission capacity and applications in emissions algorithms, Ecol. Appl., 9, 1132-1137, 1999.
Sharkey, T. D., Wiberley, A. E., and Donohue, A. R.: Isoprene emission from plants: why and how, Ann. Bot.-London, 101, 5-18, 2008.

Shim, C., Wang, Y., Choi, Y., Palmer, P. I., Abbot, D. S., and Chance, K.: Constraining global isoprene emissions with Global Ozone Monitoring Experiment (GOME) formaldehyde column measurements, J. Geophys. Res., 110, D24301, doi:10.1029/2004JD005629, 2005.

Simon, E., Kuhn, U., Rottenberger, S., Meixner, F. X., and Kesselmeier, J.: Coupling isoprene and monoterpene emissions from Amazonian tree species with physiological and environmental parameters using a neural network approach, Plant Cell Environ, 28, 287-301, 2005.

Sitch, S., Smith, B., Prentice, I. C., Arneth, A., Bondeau, A., Cramer, W., Kaplan, J. O., Levis, S., Lucht, W., Sykes, M. T. Thonicke, K., and Venevsky, S.: Evaluation of ecosystem dynamics, plant geography and terrestrial carbon cycling in the LPJ dynamic global vegetation model, Glob. Change Biol., 9, 161-185, 2003.

Siwko, M. E., Marrink, S. J., de Vries, A. H., Kozubek, A., Uiterkamp, A. J. M. S., and Mark, A. E.: Does isoprene protect plant membranes from thermal shock?, A molecular dynamics study, Biochim. Biophys. Ac., 1768, 198-206, 2007.

Stavrakou, T., Müller, J.-F., De Smedt, I., Van Roozendael, M., van der Werf, G. R., Giglio, L., and Guenther, A.: Evaluating the performance of pyrogenic and biogenic emission inventories against one decade of space-based formaldehyde columns, Atmos. Chem. Phys., 9, 1037-1060, doi:10.5194/acp-9-1037-2009, 2009.

Sun, Z., Hüve, K., Vislap, V., and Niinemets, Ü.: Elevated $\mathrm{CO}_{2}$ magnifies isoprene emissions under heat and improves thermal resistance in hybrid aspen, J. Exp. Bot., 64, 5509-5523, doi:10.1093/jxb/ert318, 2013.

van der Werf, G. R., Randerson, J. T., Giglio, L., Collatz, G. J., Mu, M., Kasibhatla, P. S., Morton, D. C., DeFries, R. S., Jin, Y., and van Leeuwen, T. T.: Global fire emissions and the contribution of deforestation, savanna, forest, agricultural, and peat fires (19972009), Atmos. Chem. Phys., 10, 11707-11735, doi:10.5194/acp10-11707-2010, 2010.

Velikova, V. and Loreto, F.: On the relationship between isoprene emission and thermotolerance in Phragmites australis leaves exposed to high temperatures and during the recovery from a heat stress, Plant Cell Environ., 28, 318-327, 2005.

Velikova, V., Várkonyi, Z., Szabó, M., Maslenkova, L., Nogues, I., Kovács, L., Peeva, V., Busheva, M., Garab, G., Sharkey, T., and Loreto, F.: Increased thermostability of thylakoid membranes in isoprene-emitting leaves probed with three biophysical techniques, Plant Physiol., 157, 905-916, 2011.

Vickers, C. E., Possell, M., Cojocariu, C. I., Velikova, C. B., Laothawornkitkul, J., Ryan, A., Mullineaux, P. M., and Hewitt, N. C.: Isoprene synthesis protects transgenic tobacco plants from oxidative stress, Plant Cell Environ., 32, 520-531, 2009.

Wan, Z.: New refinements and validation of the MODIS landsurface temperature/emissivity products, Remote Sens. Environ., 112, 59-74, 2010.

Wania, R., Ross, I., and Prentice, I. C.: Integrating peatlands and permafrost into a dynamic global vegetation model: 2. Evaluation and sensitivity of vegetation and car- 
bon cycle processes, Global Biogeochem. Cy., 23, GB3015, doi:10.1029/2008GB003413, 2009.

Williams, J. E., Strunk, A., Huijnen, V., and van Weele, M.: The application of the Modified Band Approach for the calculation of on-line photodissociation rate constants in TM5: implications for oxidative capacity, Geosci. Model Develop., 5, 15-35, 2012.
Young, P. J., Arneth, A., Schurgers, G., Zeng, G., and Pyle, J. A.: The $\mathrm{CO}_{2}$ inhibition of terrestrial isoprene emission significantly affects future ozone projections, Atmos. Chem. Phys., 9, 27932803, doi:10.5194/acp-9-2793-2009, 2009.

Zhao, M. and Running, S. W.: Drought-induced reduction in global terrestrial net primary production from 2000 through 2009, Science, 329, 940-943, 2010. 